\title{
THE USE OF SUCTION TRAPS FOR DETECTION OF UNWANTED INVASIVE INSECTS AND OTHER INVERTEBRATES
}

\author{
D.A.J. TEULON and I.A.W. SCOTT \\ Crop \& Food Research, Private Bag 4704, Christchurch, New Zealand
}

Corresponding author: teulond@crop.cri.nz

\begin{abstract}
This paper reviews the potential for using suction traps, especially existing networks, to detect unwanted exotic insects and invertebrates invading new locations. Suction traps are thought to sample small, fragile, slow and weak flying insects better than other methods. Suction traps over $6 \mathrm{~m}$ high have been shown to catch invertebrates from at least 13 different insect orders and 87 different insect families as well as Acari (mites) and Araneae (spiders). Suction traps have provided the first location records for a number of aphid species and new records of invasive species. Several issues require attention if suction traps are to become established tools for detection of unwanted invasive organisms. These include minimising the cost of traps, developing rapid identification methods, establishing the optimum location of the traps and investigating the ability of suction traps to catch species in time for remedial action.
\end{abstract}

Keywords: New Zealand, unwanted organism, invasive organism, insect, suction trap, detection method, biosecurity.

\section{INTRODUCTION}

Suction trap networks consist of a number of suction traps placed at strategic locations that continuously sample invertebrates from a fixed height above ground level. Samples are collected after a defined interval (e.g. days or weeks) and selected insects are sorted, counted and data collated. In New Zealand, six $7.5 \mathrm{~m}$ high suction traps have been erected at two sites in the North Island (Ngatarawa in Hawke's Bay and Pukekohe in South Auckland) and four sites in the South Island (Lincoln, Hilton, Rokeby and Courtenay, all in Canterbury) (Teulon et al. 2004). Funding for the installation and running of these suction traps has largely come from the wheat, squash, potato and lettuce industries. Not all suction traps have been running continuously since they were installed.

Extensive suction trap networks have been erected in Europe (12.2 m high, 73 traps in 19 countries) (Anon. 2006a), western North America (8 m high, 60 traps in 9 US states and one Canadian province) (Halbert et al. 1990) and north-central USA (6 m high, 34 traps in eight states) (Anon. 2006b). In New Zealand and elsewhere, aphid flight data and forecasts for likely crop damage are made available to interested parties (e.g. growers, crop consultants) through linked information systems (e.g. Anon. 2000; Anon. 2006b). The data collected from suction traps, especially aphid flight data, are being used to research insect dispersal, long-term population trends and climate change (Anon. 2006a).

The infrastructure and expertise provided by existing suction trap networks could form the basis for a surveillance network for unwanted aerial invasive insects and other invertebrates. In this paper 'unwanted' means species that are unwanted in a particular location because of their actual or potential pest status, and 'invasive' means species that have the potential to arrive, establish and spread to and within a new location. 


\section{OPERATION OF SUCTION TRAPS}

\section{How do suction traps work?}

Suction traps suck a standardised volume of air from a given height above ground and extract insects and other small airborne organisms from that air into a collecting device. For most existing networks, suction traps are placed at several metres above ground level to reduce the localised variation of insect density due to surrounding host plants. Insect densities within the air are known to decrease exponentially with altitude (Southwood 1966) but 'high' suction traps ( $>6 \mathrm{~m}$ above ground) are thought to be representative of flight activity for aphids over a radius of around 30-80 km (Halbert et al. 1990; Harrington \& Pickup 2006; University of Illonois 2006). Additionally, insects flying at higher levels above the ground are unlikely to be flying short distances and are thought to provide information on long-range dispersal (Cochrane \& Thornhill 1987). Wind speed and insect size are the main factors influencing the efficiency of suction traps but these are mostly a concern where absolute measurements of insect abundance are required (Southwood 1966).

\section{What variety of organisms do suction traps catch?}

The target organism for most suction trap networks has been airborne aphids. However, suction traps are effective tools for trapping other small, fragile, slow and weak flying insects. Indeed, suction traps are thought to sample these insects better than other methods (Marshall et al. 1994). Furthermore, the vast majority of alate individuals are very small (Johnson 1957) so suction traps are likely to be an effective tool for sampling a significant proportion of the airborne fauna. There have been few studies detailing the range of organisms caught in suction traps. An internet and database search (i.e. XtraMSN Search, CABI, Web of Knowledge) was therefore undertaken for studies listing organisms caught in suction traps (especially those traps over $6 \mathrm{~m}$ high) (Table 1 ). Search terms included various combinations of the following words: high, $12 \mathrm{~m}$, suction trap, Rothamsted, new record, and new species. The results indicated that 'high' suction traps catch invertebrates from at least 13 different insect orders and 87 different insect families, as well as Acari (mites) and Araneae (spiders) (Table 1). A number of different species are likely to be represented for each family so it is clear that a large number of insect species are caught in these suction traps.

For New Zealand, seven insect orders were found in samples from one $7.5 \mathrm{~m}$ suction trap, which was located at Lincoln and sampled for 1 week in each of spring, summer, autumn and winter during 2003-04 (James \& Teulon 2005). Additionally, up to 50 aphid species have been found in the same Lincoln suction trap (D.A.J. Teulon, unpubl. data) and more than 10 terebrantian thrips species were found in three New Zealand suction traps in 2002-03 (Nielsen et al. 2004).

\section{SUCTION TRAPS FOR DETECTION OF INVASIVE SPECIES Do suction traps catch invasive organisms?}

A critical factor determining whether suction traps can be used for surveillance is whether or not suction traps catch unwanted invasive organisms. Most reports listing the range of organisms caught in suction traps give little indication as to the proportion of invasive or noninvasive species found. However, the range of insect groups caught in suction traps (including aphids, thrips, bark beetles, mosquitos and vespid wasps) almost certainly includes species that are unwanted in New Zealand. No indigenous aphids have ever been reported from New Zealand suction traps. All aphid species trapped are exotic and many are unwanted pests (D.A.J. Teulon, unpubl. data). Similarly, no indigenous terebrantian thrips have been reported from New Zealand suction traps (Nielsen et al. 2004) with most of those caught being unwanted thrips pests. This probably reflects the placement of these traps in agricultural landscapes.

Do suction traps catch newly invaded organisms?

At least two reports specifically state that 'high' suction traps are used for detecting newly introduced exotic species or pests (Anon. 2006f). There are also a number of instances where suction traps (all heights) have provided the first record for a number of mostly aphid species for given locations (Table 2). It is likely that some of these records are for species that have been overlooked previously (e.g. Limonta \& Colombo 1991) but some records clearly relate to species that have recently invaded a new location 
(Harrington 1998). In New Zealand, Teulon \& Stufkens (2002) noted that up to 50\% of new aphid records between 1981 and 2002, mostly unwanted invasive species, were from the Lincoln suction trap (see also Table 2).

TABLE 1: Invertebrate orders and families recorded from 'high' $(>6 \mathrm{~m})$ suction traps.

\begin{tabular}{|c|c|c|}
\hline Order & Family & References \\
\hline Coleoptera $^{1}$ & $\begin{array}{l}29 \text { families including: Carabidae, } \\
\text { Cryptophagidae, Curculionidae, } \\
\text { Scolytidae, Staphylinidae }\end{array}$ & $\begin{array}{l}\text { Forsse \& Solbreck 1985; } \\
\text { Lacman 1986; Cochrane \& } \\
\text { Thornhill 1987; Benton et al. } \\
\text { 2002; Moore et al. } 2004\end{array}$ \\
\hline Collembola & None specified & $\begin{array}{l}\text { Benton et al. 2002; } \\
\text { Moore et al. } 2004\end{array}$ \\
\hline Dermaptera & 2 families & Moore et al. 2004 \\
\hline $\begin{array}{l}\text { Diptera }^{1} \\
{[\text { Brachycera }]} \\
{[\text { Nematocera }]}\end{array}$ & $\begin{array}{l}27 \text { families: Anisopodidae, Anthomyiidae, } \\
\text { Bibionidae, Calliphoridae, Camillidae, } \\
\text { Cecidomyiidae, Chironomidae, Chloropidae, } \\
\text { Coelopidae, Culicidae, Dixidae, Dolichopodidae, } \\
\text { Empididae, Muscidae, Mycetophilidae, } \\
\text { Lauxaniidae, Lonchopteridae, Phoridae, } \\
\text { Psychodidae, Ptychopteridae, Scathophagidae, } \\
\text { Scatopsidae, Sciaridae, Sphaeroceridae, } \\
\text { Simulidae, Syrphidae, Tipulidae }\end{array}$ & $\begin{array}{l}\text { Gillies \& Wilkes 1976; } \\
\text { Bayon et al. 1983; Linblad } \\
\text { \& Solbreck 1998; Benton } \\
\text { et al. 2002; Moore et al. } \\
\text { 2004; Shortall et al. 2006; } \\
\text { Anon. 2006c, d }\end{array}$ \\
\hline
\end{tabular}

\begin{tabular}{|c|c|c|}
\hline Ephemeroptera & None specified & Benton et al. 2002 \\
\hline $\begin{array}{l}\text { Hemiptera }^{1} \\
{[\text { Heteroptera] }} \\
\text { [Homoptera] }\end{array}$ & 12 families including Aphididae & $\begin{array}{l}\text { Benton et al. 2002; } \\
\text { Moore et al. 2004; } \\
\text { Anon. 2006e }\end{array}$ \\
\hline Hymenoptera $^{1}$ & $\begin{array}{l}4 \text { families: Apidae, Megachilidae, } \\
\text { Sphecidae, Vespidae }\end{array}$ & $\begin{array}{l}\text { Benton et al. 2002; } \\
\text { Harrington et al. 2003; } \\
\text { Moore et al. } 2004\end{array}$ \\
\hline $\begin{array}{l}\text { Lepidoptera }^{1} \\
\text { Macro \& micro }\end{array}$ & Noctuidae & $\begin{array}{l}\text { Benton et al. 2002; } \\
\text { Harrington et al. 2003; } \\
\text { Moore et al. } 2004\end{array}$ \\
\hline Neuroptera $^{1}$ & $\begin{array}{l}2 \text { families: Chrysopidae, } \\
\text { Coniopterygidae }\end{array}$ & $\begin{array}{l}\text { Bowden 1981; Marshall } \\
\text { et al. 1994; Benton et al. } \\
\text { 2002; Moore et al. } 2004\end{array}$ \\
\hline Plecoptera & None specified & Benton et al. 2002 \\
\hline Psocoptera & $\begin{array}{l}5 \text { families: Caeciliidae, Lachesillidae, } \\
\text { Peripsocidae, Psocidae, Elipsocidae }\end{array}$ & $\begin{array}{l}\text { Locatelli \& Limonta 1994; } \\
\text { Benton et al. 2002; Moore } \\
\text { et al. 2004; Anon. 2006f }\end{array}$ \\
\hline Thysanoptera $^{1}$ & Thripidae & $\begin{array}{l}\text { Benton et al. 2002; Nielsen } \\
\text { et al. 2004; Anon. 2006c }\end{array}$ \\
\hline Trichoptera & None specified & Moore et al. 2004 \\
\hline Acari & None specified & $\begin{array}{l}\text { Benton et al. 2002; Moore } \\
\text { et al. } 2004\end{array}$ \\
\hline Aranea & 4 families including Linyphiidae & $\begin{array}{l}\text { Blandier \& Furst 1998; } \\
\text { Thorbek et al. 2002; Benton } \\
\text { et al. 2002; Moore et al. } \\
\text { 2004; Anon. 2006f }\end{array}$ \\
\hline
\end{tabular}

${ }^{1}$ Order reported from Lincoln suction trap (7.5 m) by James \& Teulon (2005). 
TABLE 2: $\quad$ First records for insect species for a given location from suction traps.

\begin{tabular}{|c|c|c|c|c|c|}
\hline $\begin{array}{l}\text { No. } \\
\text { species }\end{array}$ & Year & $\begin{array}{l}\text { Suction } \\
\text { trap height }\end{array}$ & Trap location & Comments & Reference \\
\hline \multicolumn{6}{|c|}{ Aphididae } \\
\hline 1 & 1981 & $7.5 \mathrm{~m}$ & Canterbury, NZ & First record for NZ & Sunde 1984 \\
\hline 1 & 1981 & $7.5 \mathrm{~m}$ & Canterbury, NZ & $\begin{array}{l}\text { First record for } \\
\text { South Island, NZ }\end{array}$ & Sunde 1984 \\
\hline 3 & 1983-1985 & Not stated & Lombardy, Italy & New records for Italy & $\begin{array}{l}\text { Limonta \& } \\
\text { Colombo } 1991\end{array}$ \\
\hline 3 & $1986-88$ & $8 \mathrm{~m}$ & Idaho, USA & $\begin{array}{l}\text { First records for } \\
\text { Idaho and North } \\
\text { America }\end{array}$ & $\begin{array}{l}\text { Halbert et al. } \\
\text { 1990, Halbert } \\
\& \text { Pike } 1990\end{array}$ \\
\hline 1 & 1992 & $7.5 \mathrm{~m}$ & Canterbury, NZ & First record for NZ & $\begin{array}{l}\text { Eastop pers. } \\
\text { comm. }{ }^{1}\end{array}$ \\
\hline 1 & 1992-1993 & $12.2 \mathrm{~m}^{2}$ & Valtellina, Italy & First record for Italy & $\begin{array}{l}\text { Limonta \& } \\
\text { Binazzi } 2000\end{array}$ \\
\hline 6 & 1992-1993 & Not stated & Valtellina, Italy & New records for Italy & Limonta 2001 \\
\hline $13^{3}$ & $1996-1998$ & $12.2 \mathrm{~m}^{2}$ & Croatia & $\begin{array}{l}\text { First records in } \\
\text { Croatia }\end{array}$ & $\begin{array}{l}\text { Gotlin Culjak } \\
\text { et al. } 2002\end{array}$ \\
\hline 1 & 1998 & $12.2 \mathrm{~m}$ & Britain & First record in Britain & $\begin{array}{l}\text { Harrington } \\
1998\end{array}$ \\
\hline 1 & 1998 & Not stated & Florida, USA & $\begin{array}{l}\text { First record in } \\
\text { Western hemisphere }\end{array}$ & $\begin{array}{l}\text { Halbert et al. } \\
2002\end{array}$ \\
\hline 5 & 2001 & $12.2 \mathrm{~m}^{2}$ & Belgium & $\begin{array}{l}\text { Records new to } \\
\text { the region }\end{array}$ & $\begin{array}{l}\text { Jansen \& } \\
\text { Warnier } 2002\end{array}$ \\
\hline 1 & 2002 & $7.5 \mathrm{~m}$ & Canterbury, NZ & First record in NZ & $\begin{array}{l}\text { Stufkens \& } \\
\text { Teulon } 2002\end{array}$ \\
\hline 3 & & Not stated & $\begin{array}{l}\text { Friuli-Venezia } \\
\text { Giulia region, } \\
\text { Italy }\end{array}$ & First records for Italy & $\begin{array}{l}\text { Coceano \& } \\
\text { Petrovic- } \\
\text { Obradovic } 2006\end{array}$ \\
\hline \multicolumn{6}{|c|}{ Heteroptera: Dipsocoridae } \\
\hline 1 & 2001 & Not stated & Florida, USA & $\begin{array}{l}\text { First record in } \\
\text { Florida }\end{array}$ & $\begin{array}{l}\text { Halbert \& } \\
\text { Brambila } 2002\end{array}$ \\
\hline \multicolumn{6}{|c|}{ Psocoptera: Elipsocidae/Lachesillidae } \\
\hline $2^{4}$ & $1992-1993$ & $12.2 \mathrm{~m}$ & Valtellina, Italy & First records for Italy & $\begin{array}{l}\text { Locatelli \& } \\
\text { Limonta } 1994\end{array}$ \\
\hline
\end{tabular}

${ }^{1}$ Amphorophora rubi.

${ }^{2}$ These traps are described as Rothamsted traps, which are usually $12.2 \mathrm{~m} \mathrm{high}$.

${ }^{3}$ It is not clear if all species were caught in a suction trap.

${ }^{4}$ One species from each family.

There appear to be no studies examining at what stage suction traps catch invasive organisms in relation to their initial population size and geographic distribution. Halbert (2003) considered that detections of new exotic aphid species in suction traps indicated that the insects were likely to be already established. However, Harrington (1998) judged that that a new aphid found in two traps in England could have come from southern Europe on the wind. In New Zealand, lettuce aphids were found in the Lincoln suction trap earlier than they were found in lettuce crops in Marshlands approximately $20 \mathrm{~km}$ away, although they had probably been established in Marshlands for some time. 


\section{Outstanding issues}

\section{DISCUSSION}

As with many surveillance methods, suction trap networks rely on the accurate identification of the species caught. For detection of unwanted organisms the sooner this is achieved the better. Quick and accurate identification may be possible where insect monitoring of particular groups is regularly carried out for another reason (e.g. pest management, pest forecasting) but this is unlikely to occur with the vast majority of insect groups that contain unwanted organisms. Quick, accurate and cheap methods for insect identification will be required. Traditionally, identification of newly invaded and other unwanted small insects has relied on the external morphological features of adult life stages. Additionally, intercepted pest specimens are sometimes immature and may also be damaged, which can prevent correct identification. Molecular tools now enable precise and rapid identification, irrespective of the developmental stage and condition of the sample (Frey \& Pfunder 2006). Real time PCR and microarrays are two high-throughput DNA-based technologies that provide a likely way forward (e.g. Yu et al. 2004, 2005; Walsh et al. 2005, Pfunder \& Frey 2005). However, broad adoption of either of these methodologies in the area of biosecurity has been slow because of the initial expenditure required to develop the techniques.

Suction trap networks need investment to install, to run and to support the skilled technical expertise required for insect identification. Until the value of suction trap networks for detecting unwanted organisms has been established, it seems likely that suction traps will be not be used in this capacity alone. Rather, they are likely to rely on existing aphid monitoring networks with suction traps located sub-optimally for detecting unwanted organisms. 'High' suction traps in New Zealand are currently located in major agricultural areas, with traps near some major ports and on research stations.

\section{Suction traps and biosecurity}

Suction traps have proved useful for establishing the range of insects in a given location. In a number of instances, suction traps have provided the first record of an aphid species as it invades new territory. It would seem likely that this would be true for other insects, given the range that has been identified from suction traps. This alone contributes greatly to knowledge of invasive pest species (Halbert 2003). Suction traps would also be useful for delimiting the distribution of a newly invading species within a country. Where the use of suction traps has yet to be proven is in their ability to detect unwanted invasive organisms in time to reduce their impact or eradicate them.

\section{ACKNOWLEDGEMENTS}

We thank Richard Harrington (Rothamsted Research, Harpenden, UK) for unpublished suction flight data. This manuscript was improved with comments from Nigel Bell and Sue Zydenbos. It was funded by the New Zealand Foundation for Research, Science and Technology.

\section{REFERENCES}

Anon. 2006a. EXAMINE. Exploiting of aphid monitoring systems in Europe. http://www. rothamsted.bbsrc.ac.uk/examine/objectives.html (accessed 17 May 2006).

Anon. 2006b. North Central Regional Soybean Aphid Suction Trap Network http://www. ncipmc.org/traps/ (accessed 17 May 2006).

Anon. 2006c. EXAMINE. Exploiting of aphid monitoring systems in Europe. Swedish University of Agricultural Sciences (SLU). http://www.rothamsted.bbsrc.ac.uk/ examine/consortium/p15slu.html (accessed 17 May 2006).

Anon. 2006d. Insecticide Resistance Action Group. Minutes of the 12th meeting held at ADAS-Boxworth, Boxworth, England. http://www.pesticides.gov.uk/rags. asp?id=1178 (accessed 17 May 2006).

Anon. 2006e. Exploiting of aphid monitoring systems in Europe. The Aphids. http://www. rothamsted.bbsrc.ac.uk/examine/aphids.html (accessed 17 May 2006).

Anon. 2006f. EXAMINE. Exploiting of aphid monitoring systems in Europe. Summary of data and its usage. http://www.rothamsted.bbsrc.ac.uk/examine/members 1.html (/members2.html and /members3.html) (accessed 17 May 2006). 
Anon. 2000. AphidWatch. http://www.AphidWatch.com/ (accessed 17 May 2006).

Bayon F, Ayrault JP, Pichon P 1983. Role of the suction trap in the detection of flights by cereal cecidomyiids ( $S$. mosellana and $C$. tritici). Defenses des Vegetaux (No. 223): 255-266 [only abstract accessed].

Benton TG, Bryant DM, Cole L, Crick HQP 2002. Linking agricultural practice to insect and bird populations: a historical study over three decades. Journal of Applied Ecology 39: 673-687.

Blandier G, Furst PA 1998. Ballooning spiders caught by a suction trap in an agricultural landscape. Proceedings of the 17th European Colloquium of Arachnology, Edinburgh. Pp. 177-186 [only abstract accessed].

Bowden J 1981. The relationship between light- and suction-trap catches of Chrysopa carnea (Stephens) (Neuroptera: Chrysopidae), and the adjustment of light-trap catches to allow for variation in moonlight. Bulletin of Entomological Research 71: 621-629.

Cochrane J, Thornhill WA 1987. Variation in annual and regional damage to sugar beet by pygmy beetle (Atomaria linearis). Annals of Applied Biology 110: 231-238.

Forsse E, Solbreck CH 1985. Migration in the bark beetle Ips typographus L.: Duration, timing and height of flight. Zeitschrift fuer Angewandte Zoologia 100: 47-57.

Frey JE, Pfunder M 2006. Molecular Techniques for Identification of Quarantine Insects and Mites: The Potential of Microarrays. Chapter 6. In: Molecular Diagnostics: Current Technology and Applications. Horizon Scientific Press, Norwich, United Kingdom. In press [only abstract accessed].

Gillies MT, Wilkes TJ 1976. The vertical distribution of some West African mosquitoes (Diptera, Culicidae) over open farmland in a freshwater area of Gambia. Bulletin of Entomological Research 66: 5-15.

Gotlin Culjak T, Igrc Barcic I, Dobrincic R 2002. The new registered species of aphids (Hemiptera: Aphidoidea) in Croatia. Entomologia Croatica 6 (1/2): 5-22 [only abstract accessed].

Halbert S 2003. Innovative trapping of invasive pest species. Plant Industry Update. Summer 2003. Florida Department of Agriculture \& Consumer Services. http:// www.doacs.state.fl.us/pi/images/newslettersum03.pdf (accessed 17 May 2006).

Halbert S, Bramila J 2002. Dipsocoridae (Heteroptera) found for the first time in Florida. Insecta Mundi $16(1 / 3): 24$.

Halbert S, Pike KS 1990. An Asian elm aphid (Homoptera: Aphididae) new to North America. Proceedings of the Entomological Society of Washington 92: 672-674.

Halbert S, Connelly J, Sandvol L 1990. Suction trapping of aphids in western North America (emphasis Idaho). Acta Phytopathologica et Entomologica Hungarica 25 (1-4): 411-422.

Halbert S, Hibbard KL, Voegtlin DJ 2002. Schizaphis minuta (van der Goot) (Homoptera: Aphididae), new to the United States. Insecta Mundi 16 (1/3): 56.

Harrington R 1998. An aphid new to Britain. Entomologist's Record 110: 288.

Harrington R, Pickup J 2006. Rothamsted Insect Survey. http://www.rothamsted.bbsrc. ac.uk/insect-survey/index.html (accessed 17 May 2006).

Harrington R, Smith E, Hall M 2003. Assessing long-term trends in invertebrate biomass - a pilot study. Report for English Nature, Northminster House, Peterborough, U.K. 24 pp.

James DE, Teulon DAJ 2005. The variety of insects caught in a $7.5 \mathrm{~m}$ high suction trap. New Zealand Plant Protection 58: 323.

Jansen JP, Warnier AM 2002. Assessment of 2001 aphid fly activity in Belgium with the help of a Rothamsted suction trap. Parasitica 58: 31-42.

Johnson CG 1957. The distribution of insects in the air and the empirical relation of density to height. Journal of Animal Ecology 26:479-494.

Lacman E 1986. Carabidae caught by a 12 meter high suction trap. Parasitica 42 (3): 97-102 [only abstract accessed]. 
Limonta L 2001. Catture di afidi in Valtellina. Bollettino di Zoologia Agraria e di Bachicoltura 33 (2): 115-124.

Limonta L, Binazzi A 2000. Lachninae catturati in Valtellina con trappola ad aspirazione e segnalazione di una specie nuova per l'Italia (Homoptera Aphididae). Bollettino di Zoologia Agraria e di Bachicoltura 32 (3): 171-179.

Limonta L, Colombo M 1991. Risultati di un triennio di catture afidi con trappola a suzione e segnalazione di tre specie nuove per l'Italia. Bollettino di Zoologia agraria e di Bachicoltura, Ser II 23 (1): 63-70.

Linblad M, Solbreck C 1998. Predicting Oscinella frit population densities from suction trap catches and weather data. Journal of Applied Ecology 35: 871-881.

Locatelli DP, Limonta L 1993. Psocoptera captured using a suction trap in Valtellina 1992-1993. Bollettino di Zoologia Agraria e di Bachicoltura, Ser II 26 (2): 279-282.

Marshall SA, Anderson RS, Roughley RE, Behan-Pellletier V, Danks HV 1994. Terrestrial arthropod biodiversity: planning a study and recommended sampling techniques. Bulletin of the Entomological Society of Canada (Supplement) 26 (1): 1-33.

Moore A, Harrington R, Hall M, Woiwod I 2004. Temporal changes in abundance of insects of importance as bird food. Report for English Nature, Northminster House, Peterborough, U.K. 20 pp.

Nielsen M-C, Fletcher CD, Teulon DAJ 2004. Monitoring thrips with 7.5 metre high suction traps. New Zealand Plant Protection 57: 339.

Pfunder M, Frey JE 2005. Microarray based diagnostics of pest fruit flies. Agricultural Biomarkers for Array Technology Meeting, Gdansk, Poland. COST (European Cooperation in the field of Scientific and Technical Research) Action 853. http://www. cost853.ch/pdf-files/PfunderGdansk05poster.pdf

Shortal C, Harrington R, Hall M, Clark S 2006. Long-term trends in aerial insect populations. Report for English Nature, Northminster House, Peterborough, U.K. $17 \mathrm{pp}$.

Southwood TRE 1966. Ecological methods. Chapman \& Hall, London. 524 pp.

Stufkens MAW, Teulon DAJ 2003. Distribution, host range, and flight pattern of the lettuce aphid in New Zealand. New Zealand Plant Protection 56: 27-32.

Sunde RG 1984. New records of plant pests in New Zealand 4.7 aphid species (Homoptera: Aphidoidea). New Zealand Journal of Agricultural Research 27: 575-579.

Thorbek P, Topping CJ, Sunderland KD 2002. Validation of a simple method for monitoring aerial activity of spiders. Journal of Arachnology 30: 57-64.

Teulon DAJ, Stufkens MAW 2002. Biosecurity and aphids in New Zealand. New Zealand Plant Protection 55: 12-17.

Teulon DAJ, Stufkens MAW, Fletcher JD 2004. Crop infestation by aphids is related to flight activity detected with $7.5 \mathrm{~m}$ high suction traps. New Zealand Plant Protection 57: 227-232.

University of Illonois 2006. Soybean Aphids Suction Trap Network. http://www.ipm. uiuc.edu/fieldcrops/insects/soybean_aphids/suction_trap_network/index.html (accessed 17 May 2006).

Walsh K, Boonham N, Barker I, Collins DW 2005. Development of a sequence-specific real-time PCR to the melon thrips Thrips palmi (Thysan., Thripidae). Journal of Applied Entomology 129: 272-279.

Yu DJ, Zhang GM, Chen ZL, Zhang RJ, Yin WY 2004. Rapid identification of Batrocera latifrons (Dipt., Tephritidae) by real-time PCR using SYBR Green chemistry. Journal of Applied Entomology 128: 670-676.

Yu DJ, Chen ZL, Zhang RJ, Yin WY 2005. Real-time qualitative PCR for the inspection and identification of Batrocera philippinensis and Batrocera occipitalis (Diptera: Tephritidae) using SYBR Green assay. The Raffles Bulletin of Zoology 53(1): 73-78. 